Public Health of Indonesia

\title{
VULNERABILITY OF WEATHER ON COVID-19 PANDEMIC IN WEST JAVA, INDONESIA
}

\section{Ramadhan Tosepu ${ }^{1}$, Devi Savitri Effendy ${ }^{2}$, La Ode Ali Imran Ahmad ${ }^{3}$, Hariati Lestari ${ }^{4}$, Hartati Bahar ${ }^{5}$, Pitrah Asfian ${ }^{6}$, Ambo Sakka $^{3}$}

\author{
${ }^{1}$ Department of Environmental Health, Faculty of Public Health, University of Halu Oleo, Indonesia \\ ${ }^{2}$ Department of Health Nutrition, Faculty of Public Health, University of Halu Oleo, Indonesia \\ ${ }^{3}$ Department of Health Administration, Faculty of Public Health, University of Halu Oleo, Indonesia \\ ${ }^{4}$ Department of Epidemiology, Faculty of Public Health, University of Halu Oleo, Indonesia \\ ${ }^{5}$ Department of Health Promotion, Faculty of Public Health, University of Halu Oleo, Indonesia \\ ${ }^{6}$ Department of Occupational Health, Faculty of Public Health, University of Halu Oleo, Indonesia
}

Received: 29 October 2020 | Accepted: 11 November 2020

DOI: https://dx.doi.org/10.36685/phi.v6i4.357

\author{
Correspondence: \\ Dr. Ramadhan Tosepu \\ Faculty of Public Health, University of Halu Oleo \\ Southeast Sulawesi province, Indonesia \\ Jl.H.E.Mokodompit, Anduonohu \\ Email: ramadhan.tosepu@uho.ac.id
}

Copyright: (C) 2020 the author(s). This is an open-access article distributed under the terms of the Creative Commons Attribution Non-Commercial License, which permits unrestricted non-commercial use, distribution, and reproduction in any medium, provided the original work is properly cited.

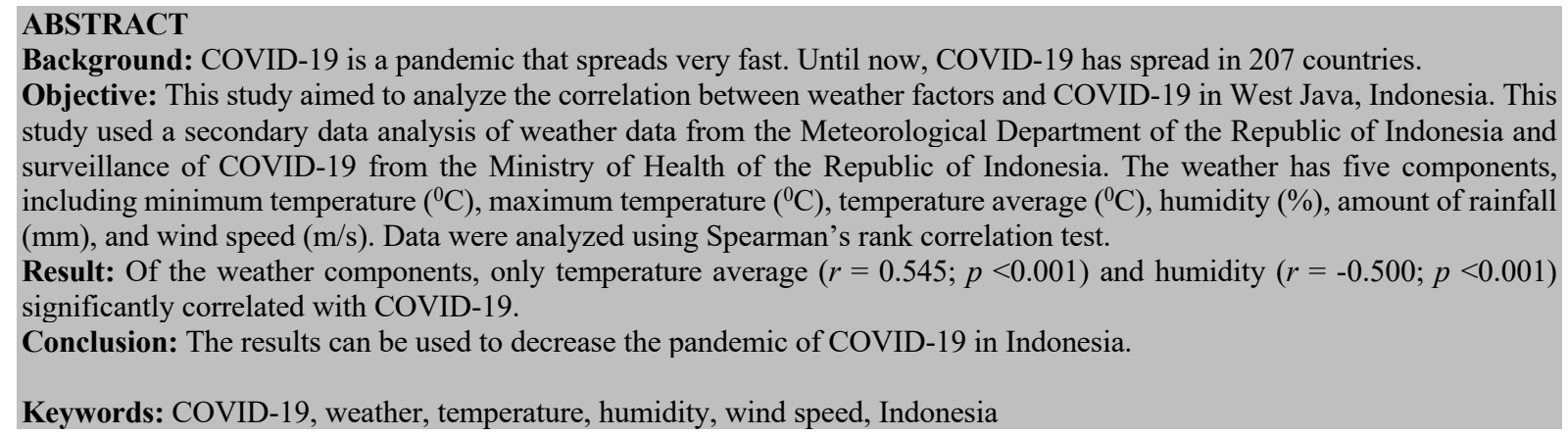

\section{BACKGROUND}

In December 2019, Wuhan, Hubei Province, China, came to international attention due to a coronavirus or COVID-19 outbreak in the area where the cause remains unknown (Wang, Horby, Hayden, \& Gao, 2020). The spread of this virus takes place very quickly, from the territory of China to several countries, including Indonesia. COVID-19 is a collection of viruses that can infect the respiratory system. The virus causes not only mild respiratory infections, such as flu, but also severe respiratory diseases, such as lung infections or pneumonia, Middle-East Respiratory Syndrome (MERS), and Severe Acute Respiratory Syndrome (SARS) (Li et al., 2020; Zhu et al., 2020). The initial symptoms of the virus infection include fever, runny nose, dry cough, sore throat, and headache. In severe cases, patients can experience high fever, cough with phlegm, and even bleeding, shortness of breath, and chest pain. These symptoms appear when the body acts against the virus (Chen et al., 2020; $\underline{\mathrm{Zu}}$ et al., 2020). The World Health Organization 
named COVID-19 as a pandemic, and until April 4, 2020, 976,249 cases and the death of 50,489 people were reported in 207 countries (World health organization, 2020).

Research conducted in California found a significant relationship between weather and pneumonia (Ebi, Exuzides, Lau, Kelsh, \& Barnston, 2001). Similarly, Haspil-Corgan, Tewari, Low, and Gauff (2004) found a significant effect on the incidence of pneumonia with temperature, humidity, and amount of precipitation. Further, Gardner et al. (2019) also found a risk of MERS disease associated with temperature and humidity. The weather consistently has an impact on the respiratory system, in the form of transmission, direct contact, or droplets, such as influenza and respiratory syncytial viruses (Lowen, Mubareka, Steel, \& Palese, 2007).

Indonesia has a tropical climate (Schollaen et al., 2013) with a huge potential for the spread of disease (Knudsen, 1995), carried by vectors, air, soil, and humans themselves. The COVID-19 case in Indonesia was first reported March 2, 2020 , in two individuals, reported as imported cases. The cases continually increased to 1,790 cases on April 2, 2020, with a 9.5\% case fatality rate, 170 deaths, and 112 recovered cases (Gugus tugas percepatan penanganan Covid-19, 2020). However, data related to weather or climate change in relation to COVID-19 remains available. Therefore, this study will contribute to the efforts in decreasing the incidence rate of COVID-19.

\section{METHODS}

\section{Study Area}

West Java, or called Jawa Barat, is located in the intermediate position $5^{\mathrm{O}} 50^{\prime}-7^{\mathrm{O}} 50^{\prime}$ ' south latitude and $104^{\circ} 48^{\prime}-108^{\circ} 48^{\prime}$ east longitude. West Java comprises a land area of $35,377.76 \mathrm{~km}^{2}$. The territorial Boundaries of West Java Province in the north are bordered by the Java Sea, the southern region by the Indian Ocean, the west by Banten Province, and the Special Province of Jakarta. In contrast, the east is bordered by Central Java Province. The biggest population resides in Bogor Regency with over 5.84 million residents, followed by Bandung and Bekasi Regency, with 3.73 and 3.63 million inhabitants, respectively.

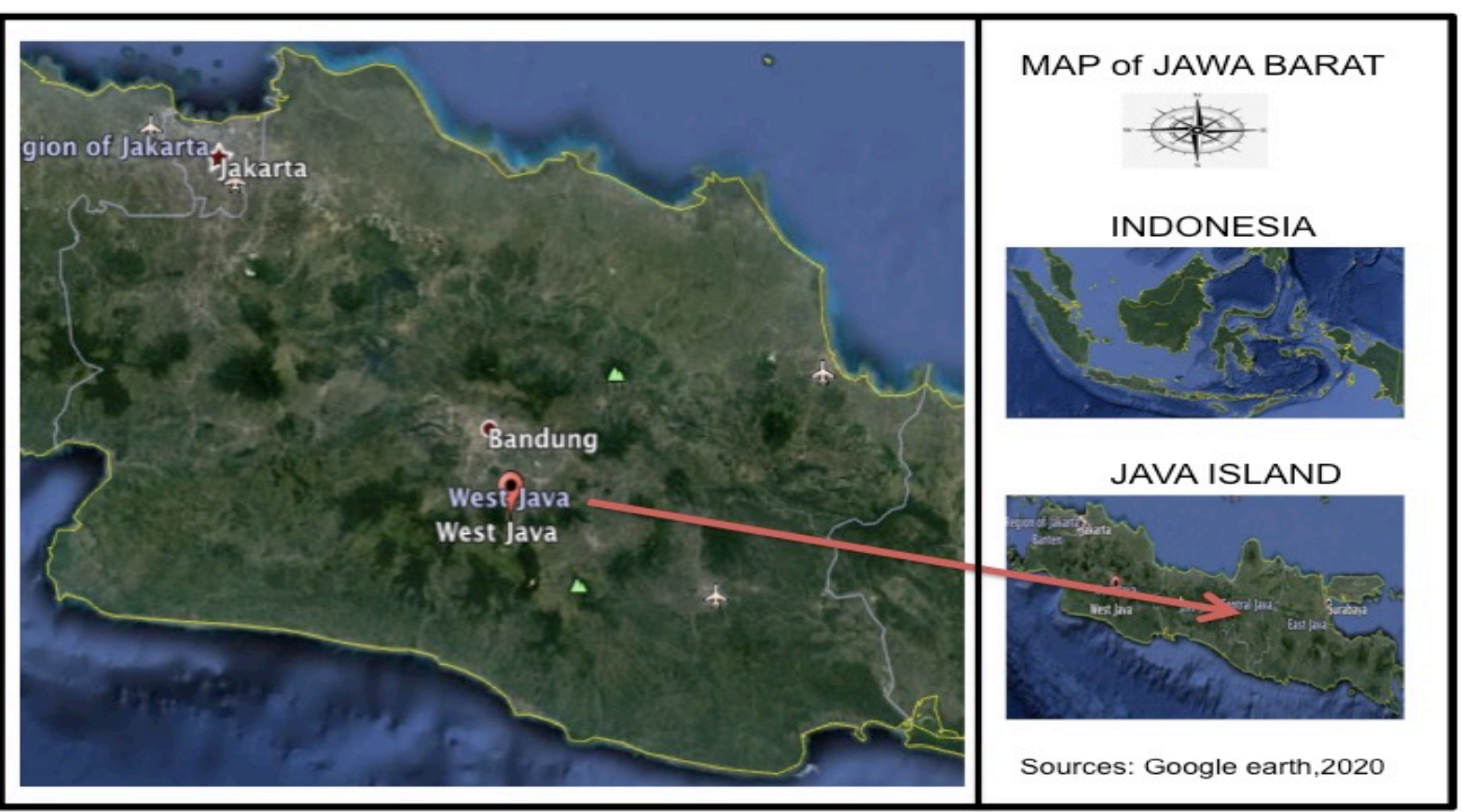

Figure 1 Map of West Java, 2020 
West Java is one of the five provinces in Indonesia, which has the highest number of cases of COVID-19. April 2, 2020, the Indonesian government reported the five highest provinces with COVID-19 cases, namely: Jakarta (897 cases), West Java (223 cases), Banten (164 cases), Central Java (104 cases), and East Java (104 cases) (Gugus tugas percepatan penanganan Covid-19, 2020).

\section{Data Collection}

The data sets on the daily cases of COVID-19 in West Java were obtained from the Ministry of Health of the Republic of Indonesia from March to April 2, 2020, while weather data were obtained from the Meteorological Department of the Republic of Indonesia. The weather data consisted of minimum temperature $\left({ }^{\circ} \mathrm{C}\right)$, maximum temperature $\left({ }^{\circ} \mathrm{C}\right)$, average temperature $\left({ }^{0} \mathrm{C}\right)$, humidity $(\%)$, amount of rainfall $(\mathrm{mm})$, and wind speed average $(\mathrm{m} / \mathrm{s})$. Lockdown in West Java starts April 15, 2020. Lockdown is not applying to all regions. Based on the regulations of the Governor of West Java, number 27 April 2020 , the areas that become lockdowns were determined: Bogor district, Bogor city, Depok city, Bekasi district, and Bekasi city.

\section{Data Analysis}

To examine the relationship between weather and COVID-19, Spearman's rank correlation test was used. Spearman's rank correlation tests are non- parametric tests that are not dependent on the data's concrete values and distributions (Dalmay, Preux, Druet-Cabanac, \& Vergnenègre, 2003). And Spearman's rank correlation can mainly measure the strength of association between two variables (Bonett \& Wright, 2000).

\section{RESULTS}

As shown in Figure 2, cases of COVID-19 in West Java increased continuously. The first discovery was 40 cases, and as of April 2, 2020, 220 cases, with 21 deaths and 11 recovered were reported, with the following weather conditions: the minimum temperature (lowest $22^{\circ} \mathrm{C}$ and highest $23.3^{\circ} \mathrm{C}$ ), maximum temperature (lowest $29.4^{\circ} \mathrm{C}$ and highest $33.4^{\circ} \mathrm{C}$ ), temperature average (lowest $25.1^{\circ} \mathrm{C}$ and highest $27.6^{\circ} \mathrm{C}$ ), humidity (lowest 78\% and highest 94\%), rainfall (lowest $1.1 \mathrm{~mm}$ and highest $121.7 \mathrm{~mm}$ ) and wind speed average (lowest $1 \mathrm{~m} / \mathrm{s}$ and highest $2 \mathrm{~m} / \mathrm{s}$ ).

In addition, Table 1 shows a significant and positive correlation between temperature average and COVID-19 $(r=0.545 ; p<0.001)$, and a significant and negative correlation between humidity and COVID-19 in West Java $(r=$ $0.500 ; p<0.001$ ).

Table 1 Spearman's correlation coefficients between COVID-19 and weather variables

\begin{tabular}{ll}
\hline Weather variable & Spearman's Correlation Coefficient \\
\hline Minimum temperature $\left({ }^{0} \mathrm{C}\right)$ & 0.107 \\
Minimum temperature $\left({ }^{0} \mathrm{C}\right)$ & 0.082 \\
Minimum temperature $\left({ }^{0} \mathrm{C}\right)$ & $0.545^{* *}$ \\
Humidity $(\%)$ & $-0.500^{* *}$ \\
Rainfall $(\mathrm{mm})$ & -0.371 \\
Wind speed average & -0.142 \\
\hline
\end{tabular}

**. Correlation is significant at the 0.01 level (2-tailed) 


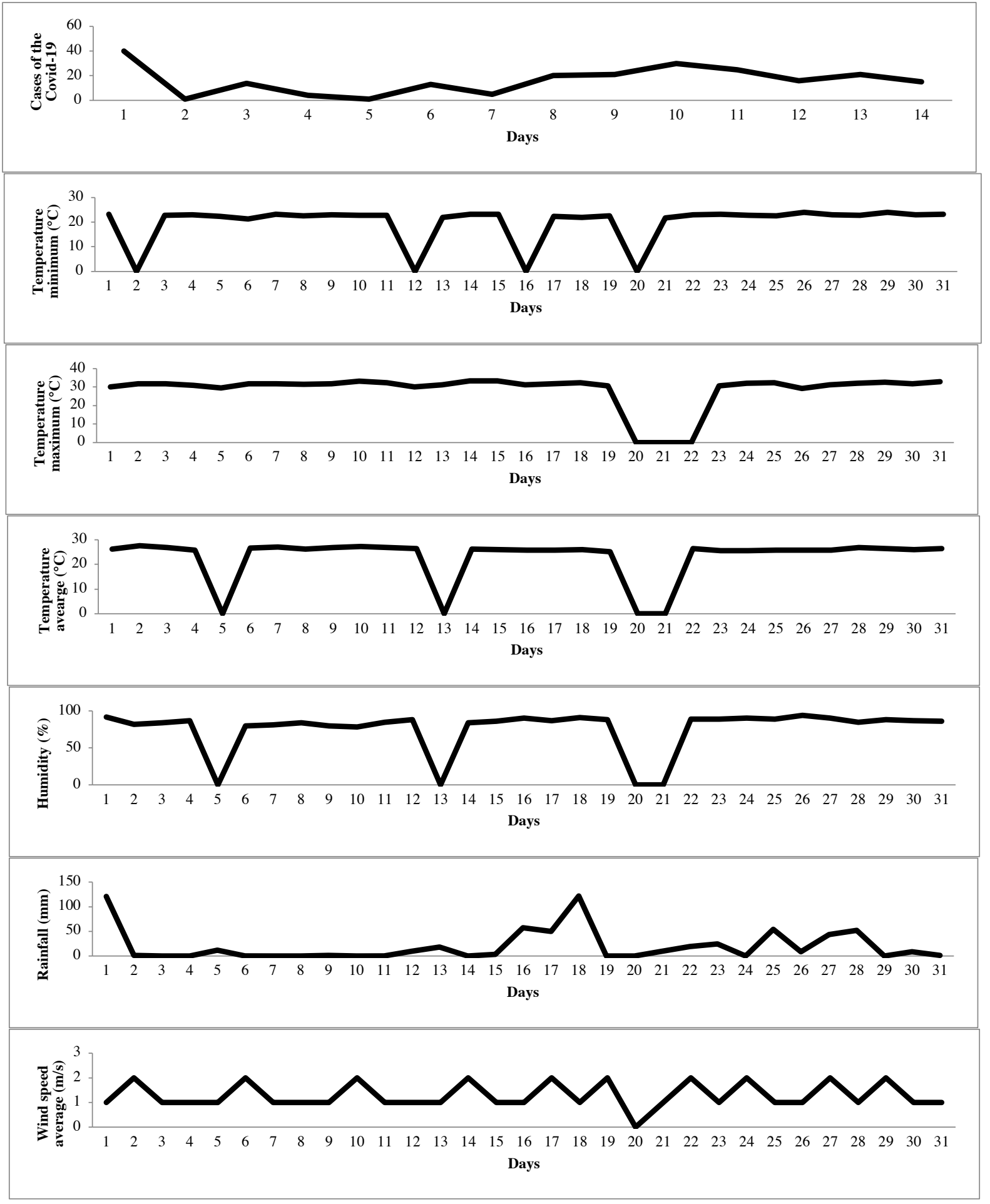

Figure 2 COVID-19 cases and weather conditions

\section{DISCUSSION}

Among the weather components, only average temperature and humidity correlated with
COVID-19. This finding was in line with Otter et al. (2016) who revealed that temperature and humidity are factors influencing SARS-CoV and MERS-CoV. Similarly, Poole (2020) found a 
correlation between the observed spread of COVID-19 (SARS-CoV-2) and climate temperature. David N. Prata et al. found that the average temperature in Brazil when the pandemic COVID-19 ranged from $16.8{ }^{\circ} \mathrm{C}$ to $27.4{ }^{\circ} \mathrm{C}$ (Prata, Rodrigues, \& Bermejo, 2020). The daily temperature has the potential of transmitting and spreading COVID-19 (Qi et al., 2020). Qi Peng Shi et al. found that there was a significant relationship between temperature and COVID-19 events. The temperature also has an important role against the COVID-19 outbreak in China (Shi et al., 2020).

Undeniably, climatic conditions could function as peak predictors of the virus. Related studies revealed that optimal temperature, humidity, and wind speed affect the survival and transmission of the SARS virus (Parkinson \& Butler, 2005; Yuan et al., 2006). Changes in weather have the potential to spread infectious diseases (Parkinson \& Butler, 2005). Malik, Awan, and Khan (2012) emphasize that rising temperatures, increasing variability in the rainy season, and extreme weather intensities have a significant impact on human health, such as an increase in the incidence of infectious diseases.

In this study, a negative correlation was found between humidity and COVID-19, indicating that the lower the humidity, the higher the spread of the virus. The lowest humidity in West Java was $78 \%$, and the highest was $94 \%$. The findings contrasting the related study revealed that respiratory viral infections were positively correlated with the amount of relative humidity in Indonesia, Malaysia, Mexico, and Hong Kong (S Paynter et al., 2013). It also contrasted with the statement that high humidity increases the survival of the virus (Stuart Paynter, Ware, Weinstein, Williams, \& Sly, 2010). In fact, lower humidity constitutes a better condition for the virus to live, as indicated in our study. However, the correlation between humidity and virus was in line with related studies by revealing that humidity was associated with the onset of an influenza pandemic (Dalziel et al., 2018; Shaman, Goldstein, \& Lipsitch, 2011).

Despite the significant findings of the weather factors on COVID-19, this study encountered limitations. First, we did not measure human behaviors such as the use of facial masks, routine hand washing, social and physical distancing, endurance, and other factors that could have affected the spread of the virus. Second, human movement from one city to another was also not evaluated, which may have affected the findings. However, this represents just a preliminary analysis of the data because the cases are continuously increasing. A larger data set is needed to strengthen the conclusion of the findings.

\section{CONCLUSION}

COVID-19 is a public health emergency problem. In that, cooperation is needed between various parties. In this study, we found weather variables such as average temperature and humidity correlated with COVID-19 in West Java, Indonesia. The findings of this study can be used as a reference to predict the increase of COVID-19 cases and suppress their incidence rates, especially in Indonesia. Another research direction is to lag the effects of meteorological factors on COVID-19 in Indonesia.

\section{Author Contributions}

Concept generation, data collection (PA and AS), writing and editing of the manuscript (RT and DES), critically reviewed (HL), writing, and revision (HB and LAI).

\section{Funding}

This research received no external funding.

\section{Acknowledgments}

Thanks to the Faculty of Public Health, the University of Halu Oleo for supporting this study, to the Climatology and Health office of Sulawesi Tenggara province for providing us with access to their data on climate and COVID-19.

\section{Declaration of Conflicting Interest}

The authors declare that they have no conflict of interest.

\section{References}

Bonett, D. G., \& Wright, T. A. (2000). Sample size requirements for estimating Pearson, Kendall and Spearman correlations. Psychometrika, 65(1), 23-28.

Chen, H., Guo, J., Wang, C., Luo, F., Yu, X., Zhang, W., . . Gong, Q. (2020). Clinical characteristics and intrauterine vertical transmission potential of COVID19 infection in nine pregnant women: a retrospective review of medical records. The Lancet, 395(10226), 809-815. 
Dalmay, F., Preux, P., Druet-Cabanac, M., \& Vergnenègre, A. (2003). Qu'est-ce qu'un test non paramétrique? Revue des Maladies Respiratoires, 20(6), 955-958.

Dalziel, B. D., Kissler, S., Gog, J. R., Viboud, C., Bjørnstad, O. N., Metcalf, C. J. E., \& Grenfell, B. T. (2018). Urbanization and humidity shape the intensity of influenza epidemics in U.S. cities. Science, 362(6410), 75-79.

Ebi, K. L., Exuzides, K. A., Lau, E., Kelsh, M., \& Barnston, A. (2001). Association of normal weather periods and El Nino events with hospitalization for viral pneumonia in females: California, 1983-1998. American Journal of Public Health, 91(8), 1200-1208.

Gardner, E. G., Kelton, D., Poljak, Z., Van Kerkhove, M., von Dobschuetz, S., \& Greer, A. L. (2019). A casecrossover analysis of the impact of weather on primary cases of Middle East respiratory syndrome. BMC Infectious Diseases, 19(1), 113.

Gugus tugas percepatan penanganan Covid-19. (2020). Laporan kasus Covid-2019. Jakarta: Indonesian National Board for Disaster Management.

Haspil-Corgan, T., Tewari, M., Low, R., \& Gauff, W. (2004). The effects of weather on pneumonia incidence. Annals of Emergency Medicine, 44(4), S37.

Knudsen, A. (1995). Global distribution and continuing spread of Aedes albopictus. Parassitologia, 37(2-3), 9197.

Li, Q., Guan, X., Wu, P., Wang, X., Zhou, L., Tong, Y., . . . Wong, J. Y. (2020). Early transmission dynamics in Wuhan, China, of novel coronavirus-infected pneumonia. New England Journal of Medicine. 382(13), 1199-1207.

Lowen, A. C., Mubareka, S., Steel, J., \& Palese, P. (2007). Influenza virus transmission is dependent on relative humidity and temperature. PLoS Pathogens, 3(10), e151.

Malik, S. M., Awan, H., \& Khan, N. (2012). Mapping vulnerability to climate change and its repercussions on human health in Pakistan. Globalization and Health, $8(1), 31$.

Otter, J., Donskey, C., Yezli, S., Douthwaite, S., Goldenberg, S., \& Weber, D. (2016). Transmission of SARS and MERS coronaviruses and influenza virus in healthcare settings: the possible role of dry surface contamination. Journal of Hospital Infection, 92(3), 235-250.

Parkinson, A. J., \& Butler, J. C. (2005). Potential impacts of climate change on infectious diseases in the Arctic. International Journal of Circumpolar Health, 64(5), 478-486.

Paynter, S., Ware, R. S., Weinstein, P., Williams, G., \& Sly, P. D. (2010). Childhood pneumonia: a neglected, climate-sensitive disease? The Lancet, 376(9755), 18041805.
Paynter, S., Weinstein, P., Ware, R., Lucero, M., Tallo, V., Nohynek, H., . . . Sly, P. (2013). Sunshine, rainfall, humidity and child pneumonia in the tropics: time-series analyses. Epidemiology \& Infection, 141(6), 1328-1336.

Poole, L. (2020). Seasonal influences on the spread of SARS-CoV-2 (COVID19), causality, and forecastabililty (3-15-2020). Causality, and Forecastabililty (3-15-2020)(March 15, 2020).

Prata, D. N., Rodrigues, W., \& Bermejo, P. H. (2020). Temperature significantly changes COVID-19 transmission in (sub) tropical cities of Brazil. Science of The Total Environment, 138862.

Qi, H., Xiao, S., Shi, R., Ward, M. P., Chen, Y., Tu, W., . . . Zhang, Z. (2020). COVID-19 transmission in Mainland China is associated with temperature and humidity: A time-series analysis. Science of The Total Environment, 138778 .

Schollaen, K., Heinrich, I., Neuwirth, B., Krusic, P. J., D'Arrigo, R. D., Karyanto, O., \& Helle, G. (2013). Multiple tree-ring chronologies (ring width, $\delta 13 \mathrm{C}$ and $\delta 180$ ) reveal dry and rainy season signals of rainfall in Indonesia. Quaternary Science Reviews, 73, 170-181.

Shaman, J., Goldstein, E., \& Lipsitch, M. (2011). Absolute humidity and pandemic versus epidemic influenza. American Journal of Epidemiology, 173(2), 127-135.

Shi, P., Dong, Y., Yan, H., Li, X., Zhao, C., Liu, W., . . Xi, S. (2020). The impact of temperature and absolute humidity on the coronavirus disease 2019 (COVID-19) outbreak-evidence from China. MedRxiv.

Wang, C., Horby, P. W., Hayden, F. G., \& Gao, G. F. (2020). A novel coronavirus outbreak of global health concern. The Lancet, 395(10223), 470-473.

World health organization. (2020). Coronavirus disease (COVID-19) outbreak situation.

Yuan, J., Yun, H., Lan, W., Wang, W., Sullivan, S. G., Jia, S., \& Bittles, A. H. (2006). A climatologic investigation of the SARS-CoV outbreak in Beijing, China. American Journal of Infection Control, 34(4), 234-236.

Zhu, N., Zhang, D., Wang, W., Li, X., Yang, B., Song, J., . . . Lu, R. (2020). A novel coronavirus from patients with pneumonia in China, 2019. New England Journal of Medicine, 382,727-733.

Zu, Z. Y., Jiang, M. D., Xu, P. P., Chen, W., Ni, Q. Q., Lu, G. M., \& Zhang, L. J. (2020). Coronavirus disease 2019 (COVID-19): A perspective from China. Radiology, 200490.

Cite this article as: Tosepu, R., Effendy, D. S., Ahmad, L. A. O. A. I., Lestari, H., Bahar, H., Asfian, P., \& Sakka, A. (2020). Vulnerability of weather on Covid-19 pandemic in West Java, Indonesia. Public Health of Indonesia, 6(4), 123-128. https://dx.doi.org/10.36685/ phi.v6i4.357 